\title{
Breast Cancer Type 2 Susceptibility Protein Staining Method
}

National Cancer Institute

\section{Source}

National Cancer Institute. Breast Cancer Type 2 Susceptibility Protein Staining Method. NCI Thesaurus. Code C122864.

An immunohistochemical technique used to detect the presence of breast cancer type 2 susceptibility protein in a tissue sample. 